ROCZNIKI PEDAGOGICZNE

Tom 11(47), numer 2 - 2019

DOI: http://dx.doi.org/10.18290/rped.2019.11.2-12

ALBERT SZUŁCZYŃSKI

\title{
REALIZACJA METODY EDWINA GORDONA W EDUKACJI MUZYCZNEJ DZIECI W WIEKU WCZESNOSZKOLNYM
}

\section{EDUKACJA MUZYCZNA DZIECI W WIEKU WCZESNOSZKOLNYM}

Brak odpowiedniej edukacji muzycznej w szkołach jest problemem budzącym zrozumiały niepokój. Jest to problem znany nauczycielom i rodzicom uczniów, a mimo to wciąż przez nich ignorowany. Brak zainteresowania odpowiednim kształceniem dziecka, w zakresie edukacji muzycznej w wieku wczesnoszkolnym, zwiększa prawdopodobieństwo braku możliwości wypracowania u niego odpowiedniej dojrzałości do podjęcia edukacji muzycznej na kolejnych etapach jego rozwoju (Gordon, 2016). Dziecko bardzo dobrze odnajduje się w roli osoby rozszyfrowującej zakodowany język dorosłych. Szybko potrafi wczuć się w atmosferę, jaką tworzą wychowujący i otaczający go rodzice. Niczym gąbka chłonie emocje i postawy wobec świata od swoich najbliższych, realizując je w swoim codziennym życiu, będąc dumnym z kolejnej nabytej umiejętności. Jest to istotny problem, który dotyczy nie tylko muzyki, ale wszystkich przedmiotów artystycznych wykładanych w szkołach. Coraz częściej da się wyczuć wśród uczniów i ich rodziców lekceważące podejście do przedmiotów artystycznych oraz do pedagogów prowadzących te zajęcia lekcyjne.

Muzyka jest dla człowieka czymś wyjątkowym i niepowtarzalnym, i tak jak inne sztuki czymś jedynym w swoim rodzaju. Stanowi ona podstawę ludzkiej egzystencji i rozwoju. Pozwala na rozwijanie wyobraźni i kreatywności. Dzięki wczesnej edukacji muzycznej dzieci uczą się słuchania, cieszenia się muzyką oraz zaangażowania w proponowane muzyczne zabawy (Gordon, 2016). Można postawić pytanie: Kiedy należy rozpocząć zabawę z muzyką? Im wcześniej, tym

Mgr Albert SzuŁCZYŃSKI - doktorant, Katedra Dydaktyki i Edukacji Szkolnej, Instytut Pedagogiki Katolickiego Uniwersytetu Lubelskiego Jana Pawła II; e-mail: albertszulczynski@wp.pl 
lepiej. Dziecko, będące w łonie matki, odbiera bodźce słuchowe dobiegające z otoczenia. Można to zauważyć w momencie, gdy reaguje na nasz głos, na muzykę puszczaną w domu, podczas której ochoczo podskakuje i ożywia się jego aktywność. Najczęściej zaś edukacja rozpoczyna się dopiero w przedszkolnej zerówce lub w pierwszych latach szkoły, gdzie stosuje się nauczanie formalne. Bardzo ważne jest, by rozpoczynać z dzieckiem edukację muzyczną w jak najmłodszym wieku. Dzięki temu rozwiną się u niego fundamenty dla nauczania. Im solidniejsze i trwalsze fundamenty przygotujemy, tym większe korzyści będzie w przyszłości przynosić edukacja (Gordon, 2016). Im większe korzyści będą płynąć z nauki, tym większa będzie satysfakcja. Im większa satysfakcja, tym silniejsza motywacja do dalszej pracy, która to znowu przyniesie określone wymierne korzyści.

Małe dzieci uczą się najszybciej poprzez obserwację. Absorbują zachowanie dorosłych oraz grupy rówieśniczej. Tutaj poważne zadanie spoczywa na ramionach dorosłych, którzy powinni odpowiednio kształtować dzieci i wzmacniać je pozytywnymi bodźcami tak, by dzieci umiały obcować z ogromną różnorodnością typów muzyki (Gordon, 2016). Nie pozwoli to zamknąć się na jeden tylko określony rodzaj muzyki, ale poszerzy horyzonty słuchowe i ubogaci muzyczne upodobania. Doprowadzi to do inkluzji dziecka w niezbadany dotąd świat różnorodnych barw, brzmienia, akustyki, agogiki i dynamiki, bez wątpienia pozytywnie wpływając na holistyczny rozwój dziecka.

Każde dziecko bowiem rodzi się z określonym poziomem muzycznych zdolności. Poziom ten może ulec zmianie na skutek wielu czynników. Jednak determinującym czynnikiem warunkującym owe uzdolnienia są uwarunkowania genetyczne. Od nich w dużej mierze zależy poziom muzycznych uzdolnień. Na owe uzdolnienia wpływ, poza czynnikami naturalnymi, ma także wychowanie. Poziom uzdolnień muzycznych może się kształtować w ciągu pierwszych dziewięciu lat życia dziecka. W dalszych latach życia potencjał umożliwiający osiąganie określonych umiejętności i tak pozostaje na poziomie dziewięciolatka (Gordon, 2016).

Celem edukacji wczesnoszkolnej jest wspieranie całościowego rozwoju dziecka. Proces wychowania i kształcenia daje dziecku możliwość odkrywania sensu działania, prowadzi do poznania wartości dobra i piękna, określa czym jest prawda. Edukacja wczesnoszkolna zaspokaja najbardziej pierwotne potrzeby rozwojowe dziecka. Dzięki takiemu wsparciu uczeń będzie gotowy do dalszej edukacji na wyższych poziomach kształcenia (Dz.U.2017 poz.356, nr 2, s. 16). Podkreślając znaczenie holistycznego i integralnego rozwoju ucznia należy zwrócić uwagę na miejsce edukacji muzycznej w tym zakresie. 
„Edukacja muzyczna, która z uwagi na swą specyfikę, doskonali percepcję słuchową, sferę emocjonalną, wrażliwość estetyczną i ekspresję twórczą, w kształceniu zintegrowanym jest codziennym elementem zajęć. Muzykowanie wspiera motywację do działań grupowych oraz wpływa na nastrój uczniów, co ma wielkie znaczenie w procesie organizacji grupy" (Dz.U.2017 poz. 356, nr 2, s. 55).

Według cytowanej powyżej podstawy programowej, obejmującej edukację wczesnoszkolną, można znaleźć konkretne odniesienia do edukacji muzycznej. Do zadań szkoły w tym zakresie należy między innymi:

„1) wspieranie wielokierunkowej aktywności dziecka przez organizowanie sytuacji edukacyjnych umożliwiających eksperymentowanie i nabywanie doświadczeń oraz poznawanie polisensoryczne, stymulujących jego rozwój we wszystkich obszarach: fizycznym, emocjonalnym, społecznym i poznawczym;

2) zapewnienie prawidłowej organizacji zabawy, nauki i odpoczynku dla uzyskania ciągłości procesów adaptacyjnych w odniesieniu do wszystkich dzieci, w tym rozwijających się w sposób nieharmonijny, wolniejszy lub przyspieszony;

3) wspieranie:

a) aktywności dziecka kształtującej umiejętność korzystania z rozwijających się umysłowych procesów poznawczych, niezbędnych do tworzenia własnych wzorów zabawy, nauki i odpoczynku" (Dz.U.2017 poz. 356, nr 2, s. 16-17).

Troska o aktywność dziecka, której najczęstszą postacią w wieku przedszkolnym i młodszym wieku szkolnym jest zabawa, może z powodzeniem znaleźć odzwierciedlenie $w$ działaniach podejmowanych $w$ ramach edukacji muzycznej poprzez realizację szeroko pojętych zabaw muzycznych. Istotny w tym zakresie jest także sposób organizacji zajęć. Zadaniem szkoły jest między innymi organizacja zajęć:

a) „dostosowanych do intelektualnych potrzeb i oczekiwań rozwojowych dzieci, wywołujących zaciekawienie, zdumienie i radość odkrywania wiedzy, rozumienia emocji, uczuć własnych i innych osób, sprzyjających utrzymaniu zdrowia psychicznego, fizycznego i społecznego (szeroko rozumianej edukacji zdrowotnej) $[\ldots]$

f) wspierających poznawanie kultury narodowej, odbiór sztuki i potrzebę jej współtworzenia w zakresie adekwatnym do etapu rozwojowego dziecka, uwzględniających możliwości percepcji i rozumienia tych zagadnień na danym etapie rozwoju dziecka;

h) umożliwiających zaspokojenie potrzeb poznawania kultur innych narodów, w tym krajów Unii Europejskiej, różnorodnych zjawisk przyrodniczych, sztuki, a także zabaw i zwyczajów dzieci innych narodowości, uwzględniających 
możliwości percepcji i rozumienia tych zagadnień na danym etapie rozwoju dziecka" (Dz.U.2017 poz. 356, nr 2, s. 17-18). W wymienionych powyżej zadaniach należy podkreślić występujące tam wartości kultury, piękna i sztuki. Realizacja powyższych zadań może odbywać się między innymi podczas edukacji muzycznej w odpowiednio przygotowanym otoczeniu. Podstawa programowa zawiera wskazania w tym zakresie. Powinna być to przestrzeń:

„b) umożliwiająca aktywność ruchową i poznawczą dzieci, nabywanie umiejętności społecznych, właściwy rozwój emocjonalny oraz zapewniająca poczucie bezpieczeństwa;

c) stymulująca systematyczny rozwój wrażliwości estetycznej i poczucia tożsamości, umożliwiająca integrację uczniów, ich działalność artystyczną, społeczną $\mathrm{i}$ inną wynikającą z programu nauczania oraz programu wychowawczo-profilaktycznego" (Dz.U.2017 poz. 356, nr 2, s.16-18).

Nauczyciel, podejmując realizację zadań i treści z zakresu edukacji muzycznej w klasach I-III szkoły podstawowej, powinien mieć świadomość, czym jest w ogóle edukacja muzyczna w szkole, także na wyższych etapach edukacyjnych. Według Podstawy programowej kształcenia ogólnego: „Powszechna edukacja muzyczna adresowana jest do wszystkich uczestników procesu edukacyjnego niezależnie od poziomu zdolności i umiejętności muzycznych, postaw, zainteresowań czy przekonań. Podstawowym jej celem jest przygotowanie świadomych odbiorców i uczestników kultury muzycznej. Muzyka jest szczególną dziedziną sztuk pięknych, która stymuluje wielostronny, harmonijny i całościowy rozwój ucznia. Poprzez realizację wszystkich jej funkcji: wychowawczej, poznawczej, kształcącej, kompensacyjno-terapeutycznej, estetycznej, integrującej, ludycznej i kreacyjnej, przyczynia się do kształtowania osobowości młodego człowieka otwartego na świat i wyzwania, które niesie współczesność. Zadaniem muzyki jest przede wszystkim rozwijanie wrażliwości, wyobraźni i kreatywności uczniów. Nie do przecenienia jest również znaczenie emocjonalne muzyki, które niesie aktywne muzykowanie i jej percepcja. Emocjonalność stanowi istotny czynnik kształtujący rozwój ucznia i determinujący postrzeganie siebie, innych ludzi i świata. Znaczącą rolę w tym procesie pełni nauczyciel muzyki, którego zadaniem jest nieustanne dążenie do uwrażliwienia ucznia na jej piękno, potrzebę obcowania z nią, przyjemność, jaką niesie oraz na uświadomienie obecności muzyki w życiu człowieka, każdej grupy społecznej, kultury i czasu historycznego. Szczególnie ważne jest, aby uczeń doświadczał radości z muzykowania. [...] Wyjątkowe znaczenie w nauczaniu i uczeniu się przez uczniów przedmiotu posiada muzyczna aktywność własna nauczyciela, który poprzez kompetencje 
warsztatowe (specjalistyczne), kreatywne, osobowościowe, dydaktyczne i wychowawcze, a także indywidualny rodzaj pasji, wchodzi w specyficzną interakcję z uczniami opartą na humanistycznych intencjach edukacji” (Dz.U. 2017 poz. 356 , nr 2, s. 21).

$\mathrm{Na}$ podkreślenie zasługuje tu rola nauczyciela muzyki. Z jednej strony jest osobą kształcącą muzycznie swoich uczniów, z drugiej - sam jest aktywny muzycznie, jest miłośnikiem muzyki i jej propagatorem.

\subsection{Znaczenie muzyki w integralnym rozwoju dziecka}

Od wielu lat można spotkać wśród wybitnych psychologów i pedagogów takie opinie, że jeśli dzieci są kształcone muzycznie, to ich osiągnięcia $\mathrm{z}$ innych dziedzin, takich jak chociażby matematyka i języki obce znacznie się poprawiają (Gordon, 2016). Gordon twierdzi jednak, że podstawowa zasada, to uprawianie muzyki w imię samej muzyki, a nie dla osiągania korzyści z innych dyscyplin naukowych (Gordon, 2016). Jak było powiedziane wcześniej, edukacja muzyczna może z powodzeniem przyczyniać się do integralnego rozwoju człowieka. Ów integralny rozwój stanowi priorytetowy cel zabiegów edukacyjnych szkoły.

Stefan Kunowski, opracowując teorię warstwicową, wskazał obszary istotne dla prawidłowego rozwoju dziecka. Zgłębiając tę teorię, można dostrzec elementy ściśle związane z edukacją muzyczną, szerzej pojmowaną jako edukacja kulturalna.

W wymiarze biologicznym (sanare) wskazuje się na ogromne znaczenie zabawy dziecka. Uznaje się, że nie dlatego się bawimy, że jesteśmy dziećmi, lecz dzieciństwo jest dane po to, by się bawić... Zabawa towarzyszy w życiu, mając wielki udział w kulturze...

I tak u niemowlaka zaważa się zabawę manipulacyjną poprzez m.in. użycie grzechotki, mającą na celu ćwiczenie ruchu rąk (Kunowski, 2000). Kolejne etapy rozwoju, ubogacane poprzez bardziej rozbudowane formy zabawy (zabawy iluzyjne i receptywne), pozwalają zauważyć, że wszelkiego rodzaju zabawy dziecięce oparte są na czynnej fantazji i grze wyobraźni, uzdalniającej do wartościowania i tworzenia ideałów (Kunowski, 2000).

Te wczesne ideały bywają często istotne przy późniejszym wyborze zawodu, w którym dziecko chce pracować. W kolejnym etapie rozwoju w warstwie biologicznej pojawiają się inne formy zabawowe, jak zabawy i gry ruchowe, gimnastyka, sport, musztra, turystyka i tańce. Sprzyjają trosce o zdrowie i wzrost energii dziecka oraz służą podsycaniu żywotności organizmu (Kunowski, 2000).

W warstwie psychologicznej (edocere) zabawa w życiu dziecka wczesnoszkolnego ,przechodząc stopniowo zmiany nasyca się coraz bardziej elementem 
poznawczym i przemienia się w dociekanie" (Kunowski, 2000, s. 207). Dociekanie jest własną aktywnością działaniową i umysłową dziecka, zwróconą na zewnątrz ku technice i wytworom ludzkiej kultury (Kunowski, 2000).

W warstwie socjologicznej (educere) wychowanek wyrasta już z zabawy dziecięcej, przerastając dociekanie. Dotychczasowe szukanie zabawy i przyjemności przeradza się w potrzebę szukania oparcia i uznania w grupie rówieśniczej, rodzinnej i szkolnej. Oznacza to, że nie dociekamy już w pojedynkę, lecz w grupie i na równi z innymi. Staramy się przypodobać grupie i spełniać narzucone przez nich normy. W trakcie intensywnego uspołeczniania się wychowanka, duży nacisk kładzie się na znaczenie pracy. Powinna ona stać się aktywnością własną, wynikającą z wolnego wyboru. W ten sposób praca nienarzucona rozwija człowieka społecznie wartościowego i dojrzałego. Wszelkie zaś formy pracy powinny być przesiąknięte twórczością (Kunowski, 2000). Jest to porównywalne do gordonowskiej akulturacji, podczas której dziecko musi się odpowiednio przygotować, aby w dalszym etapie rozwoju $\mathrm{z}$ łatwością wejść w imitację i asymilację audiacji wstępnej oraz rozwinąć gotowość do audiacji właściwej (Gordon, 2016).

W warstwie kulturologicznej (educare) pojawia się ,uczulenie wychowanka na głębsze wartości zawarte w dziełach kultury" (Kunowski, 2000, s. 211), pozostające w szczególnym związku z aktywnością własną przeradzającą się w twórczość. Próby twórczości własnej wynikają ze swoistych, odrębnych uzdolnień i talentów. Proces twórczy w każdym rodzaju aktywności kulturalnej przebiega w sposób podobny, dlatego twórczość, jako dalsza forma aktywności własnej, jest czynnikiem istotnie rozwijającym i kształtującym osobowość (Kunowski, 2000).

W warstwie światopoglądowej (initiare) spotykamy się z rozwinięciem wyżej opisanego procesu twórczego. Jest to bowiem już nie tylko pojawienie się wrażliwości na piękno, prawdę i dobro własnych wytworów. Ów „wstrząs kulturalny” przechodzi przez fazę „słyszenia kulturalnego”, chwytającego graną melodię i jej liryzm oraz „widzenie kulturalne”, pozwalające dostrzegać harmonię barw i obrazu. Te elementy „wstrząsu” prowadzą do mniej lub bardziej uświadamiającego olśnienia, czyli natchnienia, nazwanego „zasłoną Mai”. To w konsekwencji daje możliwość wejścia na etap „wędrówki duchowej”, pozwalającej zgłębiać bogactwo dotychczasowego dorobku kultury, aż dojdzie się do odnalezienia swojej drogi twórczości zakorzenionej w konkretnym nurcie - „odkrycie ojczyzny duchowej”. Jest to już głębsze przeżycie światopoglądowe, pozwalające stawiać pytania poznawcze i teologiczne, wynikające z natury mądrego człowieka. Dzięki temu rozbudowuje się synteza światopoglądu osobistego, w której 
Bóg, Absolut, będzie ujęty w kształt nadany przez twórczo wypracowaną ideę przewodnią swojego życia (Kunowski, 2000, s. 212-214).

Teoria warstwicowa Kunowskiego zajmuje się procesem nie tylko ilościowego rozwoju warstw, ale także jakościowego dojrzewania każdej z tych warstw. Dojrzewania podłoża rozwojowego każdej warstwy. „Doskonalenie struktur rozwojowych polega na tym, że w każdej z nich coś na trwałe pozostaje ze struktur niższych [...], a coś przybywa ze struktury wyższej” (Kunowski, 2000, s. 216).

W dalszej części opracowania zostanie podjęta próba ukazania dojrzewania do podejmowania twórczych działań muzycznych według koncepcji E.E. Gordona.

\subsection{Gotowość do uczenia się muzyki w szkole}

Gotowością nazywamy stan człowieka pozwalający na korzystanie z pewnego typu doświadczenia (Reber, 2000). Richard J. Gerrig i Philip G. Zimbardo piszą: „Uczenie się (learning) jest procesem, który prowadzi do względnie trwałej zmiany realnego zachowania lub jego potencjału i który opiera się na doświadczeniu" (Gerrig, 2008, s. 168).

W edukacji muzycznej ważne jest to, co wynika z wcześniejszego doświadczenia. Bazę tego stanowi trwała zmiana zachowania lub potencjału zachowania. $\mathrm{W}$ procesie uczenia się muzyki poprzez audiację, uczniowie potrafią zademonstrować jego rezultaty. Jest to dowód na podnoszenie się poziomu wykonania określonych reakcji oraz przyswojenie postaw i wartości. Te zaś elementy kształcenia wpływają na rodzaj i jakość podejmowanej aktywności. Uczenie się muzyki może następować tylko przez doświadczanie. Doświadczanie to obejmuje gromadzenie słownictwa brzmieniowego oraz wykonywanie zadanych ćwiczeń. Jest ono oparte na rozwoju uzdolnień muzycznych we wczesnym dzieciństwie (Zwolińska, 2014). „Uczeń może zidentyfikować sylaby solfeżowe we wskazanych przez nauczyciela wzorach za pomocą „matematycznych” obliczeń położenia nut (linia, pole), ale nie mając wymaganej gotowości audiacyjnej (umiejętności myślenia dźwiękami), nie będzie umiał poprawnie ich zaśpiewać" (Zwolińska, 2014, s. 134).

Nauczyciele muzyki oczekują, że przedmiotu tego da się nauczać w sposób sformalizowany. Niestety dzieci, które przychodzą do szkoły w wieku sześciu czy siedmiu lat, niemające wcześniej bliskiego kontaktu z muzyką, nie są w stanie sprostać wymogom kształcenia formalnego. Wielu zaś nauczycieli zmusza dzieci bez muzycznego przygotowania wstępnego, bez posiadanej muzycznej gotowości, do udziału w licznych szkolnych działaniach muzycznych, a rodzice często oczekują od dzieci pięknej gry na różnych instrumentach (Gordon, 2016). Dzieci 
bez uprzedniej muzycznej akulturacji powinny mieć możliwość doświadczenia niestrukturyzowanego i strukturyzowanego nieformalnego kierowania.

Kiedy nauczyciel muzyki ma niewielką wiedzę na temat tego, jak dzieci uczą się muzyki, lub tej wiedzy nie posiada wcale, uczy je w taki sposób, w jaki rozumie naśladowanie, czytanie nut oraz teorię muzyki (Gordon, 2016). Nie bierze więc pod uwagę wyczucia muzycznego posiadanego przez uczniów. Nie skupia się na tym, bo ma zbyt dużo dzieci w klasie, zbyt mało godzin muzyki w tygodniu, zbyt małą dyscyplinę podczas zajęć. Nawet najlepszy nauczyciel przedmiotu artystycznego miałby problem z podjęciem próby pracy indywidualnej z każdym z uczniów tak, by poznać jego zdolności i możliwości.

Wśród uczniów klas I-III w edukacji muzycznej nie można pomijać muzyki rozrywkowej. Jest ona bardzo popularna. Nauczyciel muzyki powinien prezentować wychowankom istniejącą relację między muzyką popularną i muzyką klasyczną, wskazać symbiozę tych pozornie różnych gatunków muzyki. Inaczej muzyka klasyczna zawsze pozostanie trudna w odbiorze. Na nauczycielu spoczywa wielki obowiązek przedstawiania muzyki z całym jej bogactwem gatunku w taki sposób, aby dziecko stało się świadomym odbiorcą, uczestniczącym w przyszłości w różnych koncertach i festiwalach muzycznych (Rogozińska, 2017).

Podsumowując dotychczasowe rozważania można stwierdzić, że w edukacji muzycznej ważna jest różnorodność dróg i sposobów realizacji tej edukacji. Poniżej zostanie ukazana jedna z tych możliwości, jaką jest metoda E.E. Gordona.

\section{CHARAKTERYSTYKA KONCEPCJI E.E. GORDONA}

Koncepcja Edwina Gordona, której charakterystyki podjęto się w niniejszym artykule, daje podwaliny muzycznego wychowania dla dzieci. Według autora tej koncepcji „,dzieci przedszkolne mogą być nauczane tak, jakby były małymi dorosłymi..." (Gordon, 2016, s. 14). Z powodzeniem możemy odnieść to stwierdzenie do dzieci w młodszym wieku szkolnym.

Gordonowska wizja kształcenia muzycznego dotyczy nie tylko dzieci w wieku przedszkolnym lub wczesnoszkolnym. Początki tej edukacji upatruje on bowiem już u dzieci w wieku prenatalnym. We wczesnym okresie życia, czyli w fazie płodowej, w prawidłowym rozwoju pewnych struktur nerwowych niezbędna jest stymulacja z otoczenia, oddziałująca na bodźce zeń docierające. Owa stymulacja jest również niezbędna do prawidłowego procesu uczenia się, które zapewni normalne zachowania się człowieka w wieku dorosłym (Hebb, 1973). 
Edwin Elias Gordon to wybitny amerykański muzyk jazzowy, pedagog i psycholog muzyki, który po latach badań opracował teorię nauczania, obejmującą wszystkie etapy rozwoju muzycznego człowieka. Teoria zakłada, że dziecko już w łonie matki uczy się znaczenia tego, co słyszy (Gordon, 1997). Jeśli zwrócimy uwagę na możliwości stymulowania naszego nienarodzonego dziecka, to skupimy się właśnie na sferze docierających do niego dźwięków. Nie jest to oczywiście jedyny czynnik wpływający na rozwój dziecka, ale właśnie dźwięk jako jedyny, poza potrzebami fizjologicznymi, pomaga $\mathrm{w}$ budowaniu relacji $\mathrm{z}$ rodzicami i światem zewnętrznym (Gawryłkiewicz, 2010). Dziecko tuż po urodzeniu łamie kod językowy i zasłyszane wcześniej dźwięki zaczyna odtwarzać, poznając ich znaczenie i budując $\mathrm{z}$ nich całe zdania. Taki sam schemat jest w przypadku nauki muzyki. Należy więc dziecko zainteresować muzyką, zainspirować własnym przykładem miłości do muzyki, by potrafiło ono przyłączyć się do zabaw muzycznych. Najważniejszym okresem dla uczenia się jest czas od pierwszych chwil po urodzeniu (a może jeszcze nawet w łonie matki) do ukończenia trzeciego roku życia. W tym czasie należy kierować dzieckiem tak, aby odbierało nieustrukturowane, nieformalne oddziaływania. Następnie między trzecim a piątym rokiem życia zaczyna się okres oddziaływań już ustrukturowanych, ale wciąż nieformalnych, realizowanych przez dom rodzinny lub przedszkole (Gordon, 1997).

W koncepcji Gordona chodzi o to, by dziecko potrafiło intuicyjnie, a nie tylko mechanicznie i odtwórczo angażować się w muzyczne projekty. Dziecko uczy się prawidłowo odtwarzać motywy muzyczne w kontekście, a nie tylko pamiętać nazwy dźwięków i ich wysokości. Jest to taki sam proces, jak uczenie dziecka języka poprzez uprzednie słuchanie go i mówienie, a dopiero potem czytanie i pisanie. Tylko w ten sposób dziecko może nauczyć się improwizacji i rozwinąć swoją twórczość. Nauczyciel nie jest w stanie tego nauczyć za pomocą notacji. Nie jest w stanie tego nauczyć bez uprzedniej wiedzy na temat audiacji wstępnej. Ten zaś rodzaj audiacji jest nierozerwalnie związany z audiacją właściwą. Stanowi to oś teorii uczenia się muzyki dotyczącej małych dzieci (Gordon, 1997).

Profesor Gordon podkreśla wielką wartość oddziaływania stymulacji muzycznej na ogólny rozwój dziecka, ale zastrzega, że uczenie muzyki nie powinno być prowadzone w celu osiągania lepszych wyników w innych dyscyplinach naukowych, lecz tylko dla samej muzyki (Gawryłkiewicz, 2010). Wyróżnił on trzy obszary uczenia się muzyki: audiację, znajomość zasad muzyki i jej wykonawstwo (Rogozińska, 2017).

Teoria Gordona w swoim centralnym miejscu stawia na audiację. $\mathrm{O}$ audiacji mówimy wówczas, gdy określony utwór muzyczny jest rozumiany oraz słyszany 
nie tylko wtedy, gdy właśnie brzmi, ale nawet wówczas, gdy już fizycznie go nie ma, bądź nawet nigdy nie zabrzmiał. Tym właśnie audiacja różni się od percepcji słuchowej, w której dźwięk musi faktycznie zabrzmieć (Gordon, 1997). Percepcja słuchowa jest konieczna dopiero po audiacji. „Dźwięk jako taki nie jest muzyką. Staje się muzyką dopiero dzięki audiacji, kiedy analogicznie jak w języku, przełożony zostanie $\mathrm{w}$ umyśle na określone znaczenie. Znaczenie to będzie równocześnie różne $\mathrm{w}$ różnych sytuacjach, także odmienne u różnych ludzi. Jakość znaczenia, jakie dana osoba może nadać muzyce w określonym czasie, jest zdeterminowana przez poziom jej uzdolnień muzycznych, zakresu wykształcenia i rozległości muzycznych doświadczeń" (Gordon, 1999, s. 24). Audiacja jest możliwa bez żadnej wiedzy na temat muzycznej notacji. Audiowanie podczas wykonywania muzyki jest tak samo kluczowe i potrzebne, jak myślenie podczas mówienia (Gordon, 2016). Kiedy język zostaje zapisany, a nie tylko mówiony, wiąże się to ze stworzeniem gramatyki, czyli określonych, odgórnych zasad jego powszechnego używania. Usystematyzowanie języka powoduje więc zdławienie kreatywności. Podobnie jest z muzyką. Tutaj stworzona teoria też dławi kreatywność, negatywnie oddziałując na improwizację (Gordon, 2016).Wyróżnia się dwa rodzaje audiacji: wstępną i właściwą.

W audiacji wstępnej nie jest najważniejsze to, jaki efekt osiągnęło dziecko, ale to jaki był jego proces dojścia do wypracowanego efektu (Gordon, 2016). Podobnie jak przy rozwiązywaniu zadania $\mathrm{z}$ matematyki, nie jest istotna droga dojścia do wyniku, lecz poprawny wynik osiągnięty dzięki prawidłowemu i logicznemu rozumowaniu.

Audiacja wstępna składa się z trzech różnego typu procesów. Do typów tych zaliczamy akulturację, imitację i asymilację, wraz z ich stadiami. Ma ona za zadanie przygotować dzieci do typów i modeli audiacji właściwej. Czas, w którym dziecko pozostanie na etapie audiacji wstępnej, nie jest do przewidzenia. Zależy to bowiem od poziomu zdolności muzycznych dziecka, jego rozwoju emocjonalnego i fizycznego. Zdarza się bowiem, że dziecko ma gotowość muzyczną do wejścia na wyższe stadium czy typ audiacji, ale nie ma odpowiedniej gotowości emocjonalnej - i vice versa (Gordon, 2016, s. 16). Nie można więc na tym etapie życia dziecka mieć zbyt dużych oczekiwań. Muzyka powinna być zabawą, czasem odprężenia i relaksu.

Po audiacji wstępnej następuje audiacja właściwa, której nadrzędnym celem jest tworzenie nieznanej muzyki i improwizacja. Dla osób działających na gruncie edukacji w jej różnych wymiarach, uczących różnych przedmiotów, niezwykle inspirująca może być sama kolejność poniższych aktywności. Jednakże wejście 
w edukację formalną bez wcześniejszego zbudowania relacji z podmiotem działań edukacyjnych, bez umiejętności asymilacyjnych: płynnego wypowiadania się (np. muzycznego), rozbudzenia zainteresowania tematyką, wydaje się nie być zbudowane na solidnych fundamentach. Może to w konsekwencji nie przyczynić się do trwałości muzycznych aktywności, ani do osiągnięcia biegłości i lekkości w tym temacie.

Gordon wyróżnia różne typy i stadia audiacji. Audiacja jest obecna przy słuchaniu muzyki, przy jej odtwarzaniu, wykonywaniu (śpiew, rytmizacja głosem, ruch rytmiczny, gra na instrumencie), tworzeniu oraz improwizowaniu. O audiacji możemy również mówić przy okazji czytania bądź zapisywania notacji muzycznej. Chodzi o to, by po usłyszeniu danej melodii, bądź po jakiejkolwiek innej formie percepcji dźwięków muzycznych, nadać im w ciszy sens i znaczenie (Gordon, 2016).

\section{PRÓBA ADAPTACJI METODY GORDONA DO WYCHOWANIA MUZYCZNEGO DZIECI W WIEKU WCZESNOSZKOLNYM}

Edukacja muzyczna ma ogromny wpływ na przygotowanie uczniów do aktywnego uczestnictwa w życiu kulturalnym. Uczestnicząc w zajęciach muzycznych, uczeń powinien mieć możliwość twórczego działania. Muzyka kształtuje kompetencje i wpływa na procesy poznawcze dzięki ekspresji muzycznej każdego z dzieci (Gawryłkiewicz, 2010).

Wśród większości uczniów w wieku wczesnoszkolnym najbardziej popularna jest muzyka rozrywkowa. Gatunek ten posiada wiele nurtów. Muzyka rozrywkowa pomaga w rozładowaniu napięcia, daje rozrywkę, tworzy atmosferę spokoju oraz, co najważniejsze, stymuluje do własnej aktywności twórczej (Gawryłkiewicz, 2010).

Z dotychczasowych rozważań wynika, że bardzo ważnym elementem rozwoju muzycznego dziecka jest systematyczność działań i podjęcie ich możliwie jak najszybciej. Rodzi się tu jednak pytanie, jak pracować z dziećmi, które wcześniej nie miały okazji zetknąć się z proponowanymi przez Gordona rozwiązaniami, czy też całą jego teorią? Jakie można byłoby podjąć kroki, by choć trochę zaszczepić w dzieciach potrzebę muzycznej edukacji? Jak wzbudzić w nich zainteresowanie do podejmowania w późniejszych latach starań o rozwój muzyczny swoich dzieci? Jak pokazać dziecku prawdziwie wartościowy świat muzyki łagodzącej obyczaje i wspierającej jego holistyczny rozwój? 
$\mathrm{Na}$ te i jeszcze wiele innych pytań nie ma jednoznacznej odpowiedzi. Każdy, znający temat pedagog, kieruje się własną intuicją i muzyczną wrażliwością. Wielu z nauczycieli nie podejmuje w ogóle prób sięgania po dobre i sprawdzone metody przysposobienia muzycznego, a nawet nie próbuje zaimprowizować czegoś, by zadziwić ucznia, by zmobilizować go do choć małego wysiłku słuchowego, udziału w koncercie, zaśpiewania utworu muzycznego itp.

Dobrą praktyką, która pozwoliłaby podawać dzieciom wartościowe treści muzyczne, byłoby łączenie ich z innymi zajęciami niemuzycznymi. Można to uczynić na wiele sposobów, dopasowując do poszczególnych przedmiotów, z którymi uczniowie mają do czynienia na etapie edukacji wczesnoszkolnej.

W edukacji polonistycznej uczeń słucha uważnie wystąpień podczas uroczystości, koncertów, przedstawień. Dzięki temu uczy się stosować w swoich wypowiedziach pauzy, zmiany intonacji, tempa oraz siły głosu (Dz.U. 2017, s. 25). Jest to efektem prawidłowego rozwoju aparatu słuchowego, nad którym pracuje się poprzez stymulowanie muzyką młodych wychowanków.

W zakresie edukacji matematycznej uczeń, wykorzystując nabywaną wiedzę na temat liczb, rozwijając umiejętność liczenia do przodu i do tyłu, może również uczyć się liczyć wartości nut, za pomocą pięciolinii określać położenie danych dźwięków, zgodnie z ich prawidłową wysokością. Podczas tworzenia łamigłówek matematycznych z pewnością przydatna będzie własna aktywność artystyczna (Dz.U. 2017, s. 27).

W zakresie edukacji społecznej uczeń zaczyna identyfikować się z określoną grupą społeczną, do której należy (Dz.U. 2017). Taka przynależność może kształtować się już poprzez właściwe dziecku upodobania muzyczne, tożsame z określoną grupą rówieśniczą. Wiąże się to również z posiadaniem tożsamości narodowej, znajomością symboli narodowych oraz umiejętnością przedstawienia historii swojej rodziny. Ważne znaczenie ma tutaj również znajomość ważności minionych epok, ich dorobku chociażby w wynalezieniu instrumentów muzycznych.

W zakresie edukacji przyrodniczej można organizować wyjścia plenerowe, lekcje w parkach, ogrodach botanicznych i zoologicznych, wykorzystując przy tym zabawy ruchowe z towarzyszeniem pląsów i zabaw rytmiczno-tanecznych, znanych dzieciom. Przykład tego możemy odnaleźć w domu urodzenia Fryderyka Chopina, w Muzeum w Żelazowej Woli. Są w nim organizowane zajęcia plenerowe z muzyką Chopina w tle. Edukatorzy nie tylko zwracają uwagę na dźwięki dobiegające $\mathrm{z}$ otoczenia, takie jak śpiew ptaków, czy szum przepływającej przez park Utraty, ale mocno akcentują wartość fragmentów kompozycji Chopina dobiegających z interaktywnych ławek rozstawionych wzdłuż alejek. 
W zakresie edukacji plastycznej warto łączyć różne formy sztuki. Organizowane w klasie wernisaże prac uczniów warto wypełniać muzyką, dostosowaną swym gatunkiem i klimatem do tematyki wystawianych prac. Uczeń podczas poznawania różnych gatunków dzieł malarskich i graficznych powinien poznać również gatunki muzyczne występujące w danym czasie i epoce. Daje to całościowy obraz pojmowania sztuki, pozwalający lepiej zrozumieć wytwory poszczególnych artystów.

Edukacja muzyczna może być również realizowana przy okazji nauki wychowania fizycznego. Grając w gry i zabawy grupowe, muzyka może stanowić niesamowity akompaniament do solowych popisów młodych sportowców. Słuchając muzyki, stosuje się również aktywność ruchową $\mathrm{z}$ wykorzystaniem klaskania, pstrykania, tupania, biegania itp. (Dz. U. 2017).

Oswajanie dzieci z różnymi gatunkami muzyki, adekwatnej do sytuacji i zlecanych im zadań, pozwoli szybciej zapaść w podświadomości uczniów. Dzięki temu zaczną same poszukiwać różnych utworów muzycznych, posługując się nimi w codziennie wykonywanej pracy. Taka forma na pewno pozwoli ukształtować bardziej wrażliwe wnętrze ucznia.

Istnieje wiele różnych sposobów, dzięki którym można rozwijać zainteresowania dzieci. E.E. Gordon czerpał wiele inspiracji, między innymi od R. Labana i E.J. Dalcroze'a, którzy poruszali ważne zagadnienia z zakresu kształcenia poczucia czasu, ciężaru i przestrzeni.

Warto, by nauczyciele dzieci $\mathrm{w}$ wieku wczesnoszkolnym mieli w zakresie swojego kształcenia akademickiego obowiązek uczestniczenia w kursach gordonowskich, gdzie nauczą się nie tylko samej zasady muzycznej edukacji dzieci, ale poznają szersze spektrum całej koncepcji Gordona.

Istnieje szereg zajęć, które można przeprowadzić z dziećmi z klas I-III szkół podstawowych. Są to między innymi:

- zabawy z elementami skoku, jak chociażby przechodzenie przez rzeczkę, które pozwalają wyczuć własne ciało i przestrzeń;

- zabawy rozwijające wyczucie ciężaru, siły, energii i czasu poprzez układanie stosu gałęzi na ognisko w określonym czasie, np. na zaimprowizowanym biwaku harcerskim;

- zabawy kształtujące czujność i rozwijające pomysłowość przez naśladowanie drugiego dziecka. Dzieci idące w parach mają za zadanie po krótkiej obserwacji, odtworzyć ruchy partnera;

- kształcenie płynności ruchów i wyczucia czasoprzestrzeni może odbywać się za pomocą zabawy w krainę wolnego poruszania się i szybkiego poruszania się; 
- kształcenie wyobraźni odbywać się może poprzez zabawę codziennymi czynnościami. Razem z dziećmi gotujemy różne potrawy w tempie wolnym, a potem szybkim. Możemy również zaimprowizować jesienne grabienie liści w ogrodzie lub bitwę śnieżnymi kulkami.

Te wszystkie przykłady ukazują możliwości wplatania teorii E.E. Gordona w edukację wczesnoszkolną.

\section{ZAKOŃCZENIE}

Jak udało się wskazać $\mathrm{w}$ powyższym opracowaniu, muzyka ma wielkie znaczenie dla człowieka. Jest niezbędnym elementem w procesie kształtowania dziecka, wpływając na jego wrażliwość, twórczość, rozwój emocjonalny i społeczny. Mimo iż muzyka powinna być uprawiana dla samej siebie, a nie w celu rozwijania innych kompetencji (Gawryłkiewicz, 2010), to należy ją jak najszerzej propagować. Na podstawie rozmów z liczną grupą nauczycieli dzieci w wieku wczesnoszkolnym, autor powyższego opracowania zauważa niepokojący fakt, iż wiedza na temat edukacji muzycznej jest bardzo niska lub czasami żadna. Nauczyciele $\mathrm{Ci}$ skupiają się na nauczaniu matematyki, języka polskiego i innych przedmiotów, nie angażując się w sferę artystyczną. Zaproponowane w powyższym artykule formy poszerzania muzycznych zainteresowań dzieci w wieku wczesnoszkolnym winny być inspiracją dla osób odpowiedzialnych za kształcenie zintegrowane.

Nauczyciele dzieci w wieku wczesnoszkolnym mogą realizować szereg zajęć i zabaw, pozwalających dziecku rozwijać swoje pasje, zainteresowania i upodobania. Jeśli nie posiadają oni odpowiedniej wiedzy lub zdolności do przeprowadzania tego typu zajęć, mogą zorganizować dla dzieci wyjścia na liczne koncerty gordonowskie, podczas których uczestnicy czynnie angażują się w przebieg koncertu.

Ci, którzy wiedzą dużo o rozwoju dziecka, zdają sobie sprawę z faktu, że możliwości uczenia się nigdy nie będą większe niż w chwilach najmłodszych lat dziecięcych. Dlatego, jak mawiał o nich Profesor Edwin Elias Gordon, ,że żartują czasami, że chcieliby umrzeć jako małe dzieci, ale najpóźniej jak tylko byłoby to możliwe" (Gawryłkiewicz, 2010, s. 12), co może dziwne, ale jest jednym z najwspanialszych życzeń dla przyszłych pedagogów i muzycznych edukatorów. 


\section{BIBLIOGRAFIA}

GawryŁkiewicz, J. GawryŁKiEwicz, M. (red.), (2010). Podręcznik do kierowania edukacja muzyczna małego dziecka wedtug teorii uczenia się muzyki Edwina E. Gordona. Kraków: Oficyna Wydawnicza „Impuls”.

Gerrig, R.J.; Zimbardo, P.G. (2008). Psychologia i życie (przeł. E. Czerniawska i in.). Warszawa: PWN

Gordon, E.E. (1999). Sekwencje uczenia się w muzyce. Umiejętności, zawartość i motywy. Bydgoszcz: Wydawnictwo Uczelniane WSP.

GoRDON, E.E. (2016). Teoria uczenia się muzyki. Niemowlęta i małe dzieci. Gdańsk: Harmonia Universalis.

GoRDON, E.E. (1997). Umuzykalnienie niemowlą i matych dzieci. Kraków: Wydawnictwo Zamiast Korepetycji.

HebB, D.O. (1973). Podręcznik psychologii (tł. J. Pałczyński, J. Siuta). Warszawa: Wydawnictwo Naukowe PWN

Kunowski, S. (2000). Podstawy wspótczesnej pedagogiki. Warszawa: Wydawnictwo Salezjańskie. REBER, A.S. (2000). Stownik psychologii. Warszawa: Scholar.

RogoziŃSKA, K. (2017). Doświadczanie muzyki wśród dzieci w młodszym wieku szkolnym. Pedagogika Przedszkolna i Wczesnoszkolna, 10/1, 93.

Rozporządzenie Ministra Edukacji Narodowej z dnia 14 lutego 2017 r. w sprawie podstawy programowej wychowania przedszkolnego oraz podstawy programowej kształcenia ogólnego dla szkoły podstawowej, w tym dla uczniów z niepełnosprawnością intelektualną w stopniu umiarkowanym lub znacznym, kształcenia ogólnego dla branżowej szkoły I stopnia, kształcenia ogólnego dla szkoły specjalnej przysposabiającej do pracy oraz kształcenia ogólnego dla szkoły policealnej, Dz.U. 2017 poz. 356., zał. Nr 2.

ZwOLIŃSKA, E.A. (2014). Zastosowanie teorii uczenia się muzyki Edwina E. Gordona w kształceniu nauczycieli. W: A. MichalsKi (red.), Wokót teoretycznych podstaw ksztatcenia muzycznego (s.133-134). Gdańsk: Wydawnictwo Athenae Gedanenses.

\section{REALIZACJA METODY EDWINA GORDONA W EDUKACJI MUZYCZNEJ DZIECI W WIEKU WCZESNOSZKOLNYM}

$$
\text { Streszczenie }
$$

Edukacja muzyczna dzieci w wieku wczesnoszkolnym, to obszar bardzo zaniedbany. Wiąże się to $\mathrm{z}$ problemami znalezienia odpowiedniego czasu, by móc się jej nauczyć, by jej nauczać lub chociażby w małym stopniu zainspirować uczniów muzyką, zmotywować ich do odnajdywania w muzyce swoich pasji, do bawienia się muzyką, do performowania. Duża liczebność klas, brak dyscypliny na lekcjach muzyki, nieodpowiednie przygotowanie nauczycieli przedmiotu (Gordon, 2016) oraz wiele innych czynników sprawiło, że głód kulturalny młodego człowieka zaspokaja muzyka popularna, koncentrująca się na komentowaniu współczesnych wydarzeń polityczno-społecznych, podsycana wielobarwnością pulsujących świateł i rozgłośniona do granic wytrzymałości (Gordon, 2016).

W poniższym opracowaniu podjęto próbę przedstawienia koncepcji nauczania muzyki dzieci w wieku wczesnoszkolnym w oparciu o metodę profesora Edwina Eliasa Gordona, która w odczuciu autora tego opracowania - może w znaczny sposób przyczyniać się do poprawy holistycznego rozwoju młodego człowieka w procesie jego wychowania i kształtowania.

Słowa kluczowe: edukacja wczesnoszkolna; edukacja muzyczna; rozwój dziecka. 


\title{
IMPLEMENTATION OF EDWIN GORDON'S METHOD IN MUSIC EDUCATION OF CHILDREN IN EARLY'S CHOOLAGE
}

\author{
S u m m a r y
}

Musical education of children in early school age is a very neglected area. It is a result of lack of time to teach it and to inspire students by music. There is no motivate them to look for a passion in it, to playing with music, to create and perform music. Too many children in the class, no discipline in music lessons, weak preparation of music teachers and a lots of other factors caused that cultural hunger of a young man is satisfied by popular music which comments social and political events with a lot of colours and lights and very loud music.

In the article there is attempted at presenting the concept of teaching children's music in early school age based on the method of Professor Edwin Elias Gordon. According to Author of the article his method can be very useful to improve the holistic development of a young man in the process of his upbringing and education.

Key words: Early school education; music education; child's development. 